This article is distributed under the terms of the Creative Commons Attribution 3.0 PL (c) Copyright by Uniwersytet Warszawski Katedra Studiów Interkulturowych Europy

\title{
Kulturoznawstwo ratownicze, czyli czego kulturoznawstwo Europy Środkowo-Wschodniej może nauczyć się od Ewy Domańskiej
}

W artykule rozważa się możliwość wzbogacenia kulturoznawstwa Europy ŚrodkowoWschodniej ideami Ewy Domańskiej - „historią ratowniczą" oraz, historią egzystencjalną". Punktem centralnym projektów Domańskiej jest założenie, że tworzona przez badaczy wiedza - także humanistyczna - winna być użyteczna w sensie zwiększania zdolności przeżyciowych. To właśnie założenie czyni koncepcje Domańskiej skrojone na miarę badań nad Europą Środkowo-Wschodnią, rejonem o teraźniejszości i przeszłości trudnej, przyszłości zaś - wciąż niepewnej. W drugiej część artykułu skupiono się na praktycznych wyzwaniach mariażu „historii ratowniczej” i badań nad kulturą regionu.

Słowa kluczowe: Ewa Domańska, historia ratownicza, kulturoznawstwo, humanistyka zaangażowana, nowa humanistyka

\section{Czym jest „humanistyka ratownicza”?}

Jak wiemy, rozporządzenie ministra nauki i szkolnictwa wyższego z 20 września 2018 r. zamieniło kulturoznawstwo w „nauki o kulturze i religii”, dodatkowo tworząc - traktowane jako osobna dyscyplina „nauki o sztuce"1. Nawet jeśli wybrzmiewa w tym geście nieobca wielu

${ }^{1}$ Szczegółowo proces zmian opisuje Piotr Jakub Fereński w tekście Jedenasty język. Przeszłość i przyszłość, w: Kulturoznawstwo polskie. Przeszłość, przestrzeń, per- 
ludziom nauki reakcja na efemeryczność kulturoznawstwa jako dziedziny wiedzy, dziedziny w znacznej mierze (od dziesięcioleci zresztą) zajętej próbą samookreślenia, budzi wątpliwość, czy zmiana nazwy na pleonazm, jakim niewątpliwie jest związek ,nauki o kulturze i religii”, cokolwiek w tej materii rozwiązuje.

Owa wstępna uwaga ma na celu uzasadnienie faktu, że w poniższym artykule nadal posługujemy się terminem kulturoznawstwo ugruntowanym zarówno na planie instytucjonalnym, jak i metodologicznym. Zaznaczmy, że jesteśmy świadomi, jak chybotliwe jest owo - zwłaszcza metodologiczne - ,ugruntowanie”. Nie jest jednak tematem tego artykułu ponowny przegląd stanowisk próbujących określić ramy kulturoznawstwa ani w planie przedmiotu badań, stosowanych metod i narzędzi czy relacji z innymi dyscyplinami, z którymi dzielą przedmiot badania (m.in. socjologia kultury, literaturoznawstwo, antropologia kulturowa, medioznawstwo), ani w polu ich stosunków wobec zagranicznych krewnych - dziedzin wiedzy takich jak cultural studies, Kulturwissenschaft czy культурология². Interesuje nas szczególna odmiana kulturoznawstwa - Kulturoznawstwo Europy Środkowo-Wschodniej - jako dziedzina wiedzy i przestrzeń praktyk badawczych, będąca reprezentantem tzw. area-studies, czyli nauk, których komponentem wiążącym jest geograficznie określony przedmiot badań, przy - typowym dla kulturoznawstwa - zachowaniu wielości używanych metod i narzędzi³. Mówiąc precyzyjniej, spróbujemy ustalić, w jakim zakresie jest możliwe (oraz jakie korzyści by przyniosło) przyswojenie przez kulturoznawstwo Europy Środkowo-Wschodniej koncepcji „historii ratowniczej' autorstwa Ewy Domańskiej'.

spektywy, red. P. J. Fereński, A. Gomóła, M. Wójcicka, M. Zdrodowska, Wydawnictwo Naukowe Katedra, Gdańsk 2018, s. 310-334, zwłaszcza s. 318-323.

${ }^{2}$ Zob. wyczerpujący artykuł na ten temat, napisany przez metodolożkę nauki prof. Monikę Walczak: Między dyscyplina a badaniami interdyscyplinarnymi: uwagi o metodologicznym statusie kulturoznawstwa w: „Roczniki kulturoznawcze” I/2010, s. $7-41$.

${ }^{3}$ Por. tamże, s. 31 .

${ }^{4}$ E. Domańska, Historia ratownicza, ,Teksty Drugie” 5/2014, s. 12-26. 
„Historia ratownicza” to jedynie jedna z figuracji idei poznańskiej historyczki i teoretyczki (inne to „historia egzystencjalna”, „humanistyka prefiguratywna"5). Nie znaczy to, że owe pojęcia są homologiczne czy nawet synonimiczne, przenika je jednak zestaw tych samych przekonan, różnice w nazewnictwie zaś albo wynikają z potrzeby zastosowań tej samej idei do innego pola badawczego (zrazu historii, w późniejszych tekstach - całej humanistyki), albo są wyrazem ewolucji tej samej idei. Aby uniknąć terminologicznego galimatiasu, a zarazem zbliżyć pole rozważań do kulturoznawstwa, będziemy odtąd postulowaną przez Domańską postawę nazywać „humanistyką ratowniczą"6. Spróbujmy - siłą rzeczy skrótowo - wyróżnić kluczowe cechy propozycji poznańskiej badaczki:

a) „Humanistyka ratownicza” jest humanistyką zaangażowaną, to jest żywo zainteresowaną wpływem badań na - mówiąc językiem Pierre'a Bourdieu - inne pola niż macierzyste pole działalności naukowej. U podstaw owego zaangażowania leży uznanie realności zagrożeń współczesności (,terroryzm, problemy stwarzane przez procesy migracyjne, wzrastający poziom biedy, kryzys demokracji, a także zmiany klimatyczne, problemy środowiskowe itd."’) i uznanie powinności humanistyki do przeciwdziałania - oczywiście w granicach dostępnych

${ }^{5}$ Odpowiednio: E. Domańska, Historia egzystencjalna. Krytyczne studium narratywizmu i humanistyki zaangażowanej, WN PWN, Warszawa 2012; E. Domańska, Sprawiedliwość epistemiczna w humanistyce zaangażowanej, „Teksty drugie” 1/2017, s. 41-59, por. zwłaszcza s. 48-52. Te same idee są explicite wymienione i we wcześniejszej książce Domańskiej (Historie niekonwencjonalne, Wydawnictwo Poznańskie, Poznań 2006), tam jednak jej podejście nie zostało objęte żadnym wyróżniającym określeniem.

${ }^{6}$ Wierzę, że ten termin: a) zachowuje sens obu wyłożonych przez Domańską projektów - historii ratowniczej i humanistyki prefiguratywnej, b) jest poręczniejszy dla naszych rozważań kulturoznawczych niż ,historia ratownicza” przez szersze (i bliższe naukom o kulturze) pole znaczeniowe „humanistyki”, c) jednoznacznie wskazuje na całość myśli Ewy Domańskiej jako swoje źródło (nie jest próbą zawłaszczenia czy rozmycia jej dokonania intelektualnego), podczas gdy humanistyka prefiguratywna używana była przez autorkę rzadziej (i dopiero od pewnego momentu).

${ }^{7}$ E. Domańska, Sprawiedliwość epistemiczna $w$ humanistyce zaangażowanej, „Teksty Drugie” 1/2017, s. 42. 
możliwości i narzędzi - tym zagrożeniom. Owo przeciwdziałanie to właśnie „ratowanie” przyszłości, impregnowanie na zło nie teraźniejszości, a czasów, które nadejdą. Najważniejszym atrybutem zdaje się tu prefiguratywność. Domańska pisze:

Przez humanistykę prefiguratywną będę tutaj rozumiała taką humanistykę, która jest w stanie wyobrazić sobie przyszłość „zawczasu”; niejako zwiastuje jej nadejście, a jednocześnie bierze udział w kształtowaniu możliwych scenariuszy przyszłości (łac. prae, pre- + łacińskie figurare, kształtować; od figura - kształt). Cechami ruchów prefiguratywnych nie jest dążenie do przejęcia władzy, ale promowanie horyzontalności i dążenie do zmian, które stymulowane są oddolnie. [...] W badaniach prowadzonych w ramach prezentowanych przez nas dziedzin mogłoby to wyglądać tak, że traktujemy humanistykę jako laboratorium i szukamy w materiałach historycznych, literaturze, sztuce itd. takich przykładów koegzystencji, łączenia i włączania, które mogłyby stanowić podstawę budowania alternatywnych [dla apokaliptycznych] scenariuszy przyszłości ${ }^{8}$.

Wynajdywanie owych scenariuszy służyć ma immunizacji za pomocą „specyficznego imaginarium społecznego", mającego na celu „promowanie postaw pożądanych dla realizacji tych możliwości”9. W tym celu humanistyka ratownicza postuluje odejście od patologicznego zainteresowania traumą, katastrofą, wszechobecną władzą, ofiarą, wykluczeniem itp. Nie oznacza to jednak, że tematyka ta winna być porzucona (sama Domańska przyznaje, że badanie zagadnień takich jak degradacja środowiska, terroryzm, ludobójstwa ,pozostaje kwestią zasadniczą"), ale warto - podpowiada - je ,analizować, formułując inne pytania badawcze niż te, których efektem było wykazanie niemożności działań podmiotu i wspólnoty oraz determinizmu opresyjnej władzy" Domańska twierdzi kategorycznie, że byłoby lepiej dla nas (a zwłaszcza dla tych, którzy przyjdą po nas), gdyby humanistyka zaczęła pełnić rolę afirmacyjną, formacyjną i subwersyjną jednocześnie. Afirmacyjną

\footnotetext{
${ }^{8}$ Tamże, s. 49-50.

${ }^{9}$ Tamże, s. 43.

${ }^{10}$ E. Domańska, Historia ratownicza, s. 22.
} 
w sensie kontrastu wobec dominującego fatalizmu cechującego część badań nad przeszłością i kulturą. Formacyjną - czyli świadomą funkcji etycznej i wychowawczej zarówno samych badań, jak i całości praktyk akademickich ${ }^{11}$. Subwersyjną zaś $\mathrm{w}$ sensie podważania zarówno „pozytywistycznego”, „tradycyjnego” paradygmatu ograniczonego do kumulacji wiedzy, jak i opozycyjnego wobec niego - czerpiącą przede wszystkim z myśli Michela Foucaulta - nurtu krytycznego, któremu zawdzięczamy w jego rozmaitych modalnościach bezcenne (i wciąż trwające) obnażanie okrucieństw praktyk wszechobecnej władzy, ale i nurtu wzbraniającego się przed przedstawieniem projektu przeciwdziałania rzeczonym okrucieństwom ${ }^{12}$. Humanistyka ratownicza ma nie tylko służyć poszerzaniu dorobku kulturowego, ani nawet wzbogacaniu indywidualnego życia, jak pisała Maria Janion ${ }^{13}$, ale być zawsze gotowa wykorzystywać swój potencjał do transformacji społecznej ${ }^{14}$.

b) „Humanistyka ratownicza” postuluje metodologiczny rygoryzm i oparcie się na teorii ugruntowanej. Ewa Domańska wielokrotnie powtarza o wartości rzetelnego warsztatu badawczego i konieczności „redyscyplinizacji” i „reprofesjonalizacji” dyscyplin humanistycznych i społecznych wobec krzewiącego się przekonania (znajdującego wyraz w praktyce), że „każdy może się zająć wszystkim”"15. Alternatywą ma być

${ }^{11} \mathrm{Już}$ w wydanych w 2006 r. Historiach niekonwencjonalnych autorka przyznawała (tam w kontekście łączenia przez badaczy tradycyjnego warsztatu historyka $\mathrm{z}$,umiejętnością krytycznego i teoretycznego myślenia”, że nie tyle liczy na aktualnie osadzonych w swoich praktykach badaczy, ile na to, że „można kształtować nowe pokolenia historyków”, E. Domańska, Historie niekonwencjonalne, s. 218.

${ }^{12}$ Dodatkowo często - jak udowadnia w Historiach niekonwencjonalnych - ów emancypacyjny deklaratywnie dyskurs sam potrafi ,więzić” ofiarę w roli przedmiotu, miast ją upodmiotowić, wyposażyć w sprawczość.

${ }^{13}$ M. Janion, Humanistyka: poznanie i terapia, PIW, Warszawa 1974, s. 220

${ }^{14}$ Ów potencjał jest - nie jest Domańska romantycznym lekkoduchem - mocno ograniczony. Dlatego też pisząc o utopijnym wątku swojego projektu, używa sformułowania „realistyczna mikroutopia”, czyli utopia, która jest możliwa w „ograniczonej czasowo i przestrzennie skali lokalnej [...] na potrzeby konkretnej społeczności dla wspomożenia dobrostanu jej członków”, E. Domańska, Sprawiedliwość..., s. 51.

${ }^{15}$ E. Domańska, Historia egzystencjalna, s. 164. 
metoda badań czerpiąca $\mathrm{z}$ teorii ugruntowanej ${ }^{16}$, postulująca: 1) prymat empirii nad teorią (,nie narzucaj na dane z góry przyjętych kategorii, ale pozwól kategoriom wyłonić się z danych"17); 2) budowanie teorii małego zasięgu na podstawie dostępnych i przedstawionych danych. Użycie teorii ugruntowanej jest wyrazem sprzeciwu wobec praktyk badawczych, gdzie interpretacja materiału badawczego za pomocą dostępnej teorii powoduje często, że same ,wyniki badań są tylko potwierdzeniem przyjętych wcześniej tez"18. Za przykład niepopełniającej tego błędu praktyki badawczej Domańska podaje studium przypadku w perspektywie porównawczej. Zaznacza przy okazji, że perspektywa porównawcza skupia się na „znajdowaniu podobieństw, pozwala [...] na odkrycie uniwersalnych aspektów zjawisk i wyjście poza forowaną przez postmodernizm wiedzę fragmentaryczną" ${ }^{19}$. Takie podejście badawcze ma też taką zaletę, że wymyka się - zdaniem autorki - zarzutom o redukcjonizm (dzięki perspektywie porównawczej) i „o nieuprawnione generalizacje i powierzchowność" (dzięki głebokiej analizie przypadków) ${ }^{20}$.

c) „Humanistyka ratownicza” jest projektem egzystencjalnym. Twierdzenie to wybrzmiewa na kilku płaszczyznach, które - zaryzykujmy tezę - łączy postulat „zaangażowania w bycie”. Cóż to ma znaczyć? Zrazu tyle, że „humanistykę ratowniczą” interesuje nie tylko sam projekt badawczy (i teoretyczny, i praktyczny), przedmiot badania czy nawet sam badacz. W polu zainteresowań Domańskiej jest relacja wszystkich wymienionych z byciem, stanowiąc zawsze punkt wyjścia do refleksji nad pytaniami o „kondycję ludzką, kondycję planety, kon-

${ }^{16}$ Por. K. Konecki, Studia z metodologii badań jakościowych: teoria ugruntowana, PWN, Warszawa 2012.

${ }^{17}$ U. Kelle, Different Approaches in Grounded Theory, za: E. Domańska, Historia egzystencjalna, s. 173.

${ }^{18}$ K. Konecki, Teoretyzowanie w socjologii, za: E. Domańska, Historia egzystencjalna, s. 170.

${ }^{19}$ Co ważne w kontekście ratowniczego aspektu całego projektu: na tym, co wspólne, można budować relację, jeśli nie porozumienie, K.E. Domańska, Historia egzystencjalna, s. 174.

${ }^{20}$ Tamże, s. 175. 
dycję humanistyki" ${ }^{21}$. Po wtóre, zaangażowanie w bycie jest wpisane w jej prefiguratywny element: humanistyka ratownicza chce wzmocnić sprawczość, podmiotowość i kompetencje wspólnotowe tych, którzy będą odbiorcami tak tworzonej wiedzy w procesie transferu (studentów, czytelników). Jest zatem zainteresowana tym, jakich odbiorców tworzy. Wreszcie jest egzystencjalna, bowiem kluczowym zagadnieniem przenikającym wszystkie wymienione dotąd (łącznie z postulatem naukowej rzetelności) jest zagadnienie cnoty. Domańska, żywo zainteresowana imperatywem doskonalenia siebie ${ }^{22}$, nie tylko postuluje istotność cnoty oraz „orientacji na wartości” w życiu codziennym, ale przypomina też o ich ścisłym związku z ,rozwiązywaniem problemów wiedzy”23, czyli epistemologią cnoty: bo czyż szczerość, odpowiedzialność, bezstronność czy rzetelność nie są warunkami koniecznymi uprawiania dobrej nauki, nawet w perspektywie pozytywistycznej? A skoro one, to czy lepszej nauki nie przyniosłoby (już w perspektywie ratowniczej, czyli biorącej pod uwagę aspekt użyteczności i zdolności przetrwaniowych, a także - jako skutek poniekąd uboczny - budowanie trwalszych wspólnot akademickich) inkorporacja wartości takich jak otwartość, życzliwość, troskliwość?

d) „Humanistyka ratownicza” wreszcie - co wynika z powyższych i je przenika - jest próbą zajęcia nowej pozycji w polu badań humanistycznych. Osobność pozycji wynikać może rzecz jasna z potrzeby odróżnienia swoich badań od innych w procesie walki o indywidualne uznanie $^{24}$, ale równolegle nie do przeoczenia jest wysiłek, jaki wkłada Domańska w podkreślenie ładunku koncyliacyjnego swego projektu. Próbuje wyjść poza dualizm ortodoksja-herezja ${ }^{25}$ i stworzyć utopijne „poro-

${ }^{21}$ E. Domańska, Historia ratownicza, s. 18.

${ }^{22}$ E. Domańska, Historia egzystencjalna, s. 180-181.

${ }^{23}$ Słowa Johna Greco, za E. Domańska, Historia egzystencjalna, s. 182.

${ }^{24} \mathrm{Co}$ jest, rzecz jasna, praktyką, której nie potępiamy, wprost przeciwnie, jest niezbędna do przyrostu wiedzy.

${ }^{25}$ Być może nie bez znaczenia jest fakt, że aktualnie panuje relatywna symetria między tymi obozami. Heretyckie dawniej dyskursy poststrukturalistyczne i postmodernistyczne same zaczęły zajmować pozycje władzy wraz z obejmowaniem przez 
zumienie ponad podziałami" w imię zapewnienia, by i herezja, i ortodoksja (do jakiejkolwiek postawy badawczej będą te terminy odsyłać w przyszłości) mogły kontynuować swoje drobne konflikty o mniejszą - z perspektywy przetrwania - stawkę. Domańska odżegnuje się od ortodoksji nauki pozytywistycznej, przyswajając konsekwencje epistemologiczne paradygmatu interpretatywno-konstruktywistycznego ${ }^{26}$, a jednocześnie bezlitośnie wylicza słabości wyrosłej na podglebiu postmodernizmu humanistyki emancypacyjnej (m.in. konsekwencje poznawczo uprzywilejowanego statusu ofiar ${ }^{27}$ ) czy zagrożenia będące wynikiem dyskursów skierowanych na traumę ${ }^{28}$. Ba - przewrotnie, uprzedźmy - postuluje wręcz, by „zapomnieć o Foucault”29. Próbuje przełamać monopol „lewicy” na zarządzanie dyskursem emancypacyjnym, a zarazem wynieść myślenie w kategoriach wartości „poza konserwatywną politykę”30, która jest ich głównym dysponentem. Chętnie posiłkuje się idiomem posthumanizmu

ich reprezentantów coraz to bardziej prominentnych stanowisk i wysokich tytułów, ale wciąż - przeglądając katedralne czy wydziałowe publikacje - widać dużą rozbieżność i jawną wrogość wobec postaw przeciwnych (np. cytowane już Kulturoznawstwo polskie...).

${ }^{26}$ Czyli przede wszystkim brak wiary w „bezstronność” badacza i jego absolutny, pozbawiony kontaminacji obiektywizm. Por. zwłaszcza rozdział 3 „Fakt Historyczny” w: E. Domańska, Historia egzystencjalna, s. 77-97.

${ }^{27}$ Tamże, s. 122; zwłaszcza s. 125 i n.

${ }^{28}$ Tamże, s. $136-139$.

${ }^{29}$ Radykalizm wezwania, ze względu na potencjał do manipulacji, wymaga dłuższego i tonizującego cytatu: „Jeżeli w tym momencie czytelnik poczuje się zmęczony rozważaniami o relacji wiedzy i władzy, o ucisku, ofiarach, marginalizacji i wykluczeniu, to solidaryzuje się z nim w tym znużeniu", tamże, s. 144. Na marginesie warto dodać, że i sam Michel Foucault w późnej fazie swej twórczości odczuł chyba podobne znużenie i zajął się - znacznie bliższą równiez Ewie Domańskiej - tematyką samodyscypliny, podmiotowości i sprawczości, por. Por. P. Sloterdijk, Musisz życie swe odmienić, przeł. J. Janiszewski, WN PWN, Warszawa 2014, s. 209 i kolejne.

${ }^{30}$ Tamże, s. 181. Na marginesie warto rozważyć, że owo myślenie w kategoriach wartości już zostało wyniesione poza domenę „prawicy”, tak jak „postęp” - w niektórych przynajmniej znaczeniach - zadomowił się w myśi i leksykonie liberalnej prawicy (zwłaszcza tzw. hyperprawicy). Por. stawiający tezę kontynuacji tej wielkiej migracji kluczowych idei tekst Piotra Graczyka Nick Land i hiperprawica deleuzjańska, „Kronos” 3/2015, s. 130 i n. 
i transhumanizmu oraz krytyki ekologicznej, ale nie w celu folgowania intelektualnym modom czy czczego szukania niezagospodarowanych intelektualnie pól do naukowej uprawy, lecz uznając, że jest w nich potencjał pozytywny: tworzy nową perspektywę do krzewienia empatii ${ }^{31}$ i postaw wspólnotowych (obejmujących i ludzkie, i nie-ludzkie podmioty $)^{32}$. Myśli w perspektywie planetarnej, zachęcając jednocześnie do „deperyferializacji polskiej nauki” i tworzenia własnych teorii i praktyk, nieograniczających się do kalkowania zachodnich pomysłów. Innymi słowy, szuka ,trzeciej drogi” i dba, by jej manifest był maksymalnie inkluzywny i nie tracił na sile perswazyjnej niezależnie od przebiegu linii demarkacyjnych ideologii i preferencji politycznych.

Nim przejdziemy do rozważenia aplikacji postulatów humanistyki ratowniczej w ramach kulturozawstwa, spróbujmy podsumowania słowami samej Ewy Domańskiej:

Być może chodzi zatem o to, by nasze prace badawcze stały się częścią zorientowanej na przyszłość humanistyki odbudowującej poczucie bezpieczeństwa i wspierającej więzi międzyludzkie i międzygatunkowe, zaufanie i szacunek do drugiego człowieka i innych form życia (etyka troski, etyka solidarności, etyka szacunku i wzajemności) oraz więzi z naturą,

${ }^{31}$ E. Domańska, rozmowa z prof. Robertem Harrisonem w audycji Entitled opinions (about Life and Literature), audycja o tytule Posthumanism, 6 czerwca 2012, https://podcasts.apple.com/pl/podcast/entitled-opinions-about-life-and-literature/ id81415836 [dostęp 29.10.2019].

${ }^{32}$ Rozszerzanie to zaś następuje w duchu akceptacji faktu wzajemnego połączenia rozmaitych (w tym i nieludzkich) aktorów w ramach planetarnego współbycia. Sama Domańska przytacza słowa Raymonda Pierottiego i Daniela Wildcata: „nie jest to kaznodziejski i romantyczny frazes, ale uświadomienie sobie, że pojedynczy organizm nie może istnieć w oderwaniu od sieci innych żyjących form, które go otaczają i czynią jego egzystencję możliwą", Luka paradygmatyczna we współczesnej humanistyce w: Mody. Teorie i praktyki, red. E. Winniecka, Wydawnictwo Poznańskiego Towarzystwa Przyjaciół Nauk, Poznań 2018, s. 30. Por. także Timothy Mortona koncepcje interconectedness (wzajemnego połączenia rzeczy) w ramach tzw. głębokiej ekologii, A. Marzec, ,,Jesteśmy połaczonym z sobq światem”- Timothy Morton i widmo innej wspólnoty, „Teksty Drugie” 2/2018, s. 88-101. 
a także idee życia wspólnotowego rozumianego w kategoriach kolektywu ludzkich i nieludzkich podmiotów. Może się jednak okazać, że sytuacja społeczno-polityczna w Europie Środkowo-Wschodniej zmobilizuje czy nawet zmusi badaczy z tego rejonu świata, by skupili się na jego specyfice, dostosowując dyskusje na temat sposobów i potrzeb tworzenia wiedzy do lokalnych zapotrzebowań ${ }^{33}$.

O czym moglibyśmy mówić, mówiąc o „kulturoznawstwie ratowniczym Europy Środkowo-Wschodniej”

Celowo zakończyliśmy pierwszą część tekstu zdaniem rozważającym wezwanie, jakie rzucają lokalne, środkowoeuropejskie, potrzeby tutejszym badaczom. Nim jednak spróbujemy rozważyć tę kwestię, warto - jak sądzę - zwrócić uwagę na kilka konsekwencji projektu ,humanistyki ratowniczej".

Po pierwsze, mimo deklaracji autorki o potrzebie odideologizowania i odpolitycznienia badań, projekt ten jest - jak każda próba praktykowania nauki zaangażowanej - tyleż polityczny, co ideologiczny. Żeby uporządkować kwestie leksykalne: porzucamy tu silnie pejoratywnie nacechowanie słowa ,ideologia” w polszczyźnie i pozostajemy przy rozumieniu ideologii jako systemu przekonań, które thumaczą pewnej grupie jej sytuację w świecie (tak przeszłą, jak i teraźniejszą), oraz dostarczają model przyszłości wraz z praktycznymi strategiami jego osiągnięcia $^{34}$. Projekt Domańskiej zaś wypełnia granice powyższej definicji ideologii. Dodatkowo, postulując nasączenie myśleniem etycznym i aksjologicznym zarówno naszych wyborów co do przedmiotu badań, jak i przyjmowanych wobec nich metod, proponuje działanie, które jest

${ }^{33}$ E. Domańska, Luka paradygmatyczna..., s. 30.

${ }^{34}$ Tak rozumiana ideologia pojawia się (z drobnymi różnicami) u Geralda Gutka, Ericha Fromma czy Andrew Heywooda w perspektywie rozważań o splocie ideologii i - odpowiednio - edukacji, religii i polityki, za: R. Włodarczyk, Ideologia, teoria, edukacja. Myśl Ericha Fromma jako inspiracja dla pedagogiki współczesnej, Impuls, Kraków 2016. 
stricte polityczne, bo czymże jest polityka, jeśli nie polem transferu i negocjacji wartości w sferze publicznej ${ }^{35}$ ?

Wspominamy o tym, albowiem to odżegnywanie się od ewidentnej polityczności projektu Domańskiej stanowi jego słabość, a nie sama polityczność. O ile ostrożność w szafowaniu pojęciami „ideologia” i „polityka” jest typowa dla większości badaczy w Europie Środkowo-Wschodniej - na terminach tych nadal ciąży odium ich historycznych uwikłań $^{36}$ - to w przypadku „humanistyki ratowniczej” nosi znamiona zbytecznej pozy i jedynie wspomniana wyżej domniemana potrzeba inkluzywności projektu obliczonego na udział w tak ambitnym przedsięwzięciu jak udział w ocaleniu ludzkości stanowi logiczne tego wythumaczenie.

My jednak spróbujmy z owej polityczności „humanistyki ratowniczej” uczynić jądro otwieranych kulturoznawstwu Europy Środkowo-Wschodniej możliwości. Jeśli zgodzić się, że przedmiot jest terenem pogranicza o wciąż nieustalonych granicach między narodami, państwami, religiami, tyglem tyleż kulturowym, co politycznym, to ratowniczość lokalna nie może uciec do tematyki władzy, nie może twierdząco odpowiedzieć na wezwanie Domańskiej, aby „zapomnieć Foucault”, choć jednocześnie, i nieco przewrotnie, może się z poznańską badaczką zgodzić: w lokalnej specyfice rzeczywiście znużenie może budzić śledzenie relacji wiedzy i władzy, ale głównie dlatego, że w Europie Środkowo-Wschodniej w oczy rzuca się inny, jeszcze niebezpieczniejszy splot: władzy i przemocy. W rejonie, gdzie toczy się realna - choć niewypowiedziana - wojna, cyniczny populizm polityczny zaś każe odgrywać nuty wielkościowych mitów swoich narodów, głaskać radykalne

${ }^{35}$ Można argumentować, że każdy zwrot autopojetyczny (z wyjątkiem praktyk eremickich) jest gestem politycznym w tym sensie, że surplus uzyskanej w toku doskonalenie siebie energii znajduje zazwyczaj ujście w geście perswazyjnym, praktyce namawiania innych do zmiany. Manifest humanistyki ratowniczej niewątpliwie to czyni.

${ }^{36}$ Por. świetny tekst Michała Kuziaka na temat tego, jak związki polityczności i humanistyki postrzegają sami badacze, Czy polska humanistyka jest polityczna? Rekonesans, w: Nowa humanistyka. Zajmowanie pozycji, negocjowanie autonomii, Wydawnictwo IBL PAN, Warszawa 2017, s. 542-559. 
szczepy nacjonalistów, czyli innymi słowy, tu i teraz wezwanie Domańskiej, by skierować się ku praktyce naukowej i akademickiej „odbudowującej poczucie bezpieczeństwa i wspierającej więzi międzyludzkie", kładącej akcent na to, co służy stabilności i demokratyzacji, wzmacniającej podmiotowość i sprawczość jako cnoty niezbędne do tworzenia ośrodków powinno padać na podatny grunt ${ }^{37}$.

Innym elementem wartym zauważenia jest fakt, że tak pojęte kulturoznawstwo zyskałoby szanse na odróżnienie się od mnogości innych kulturoznawstw”. Marta Wójcicka w podjętej przez siebie próbie „raportu terenowego" polskiego kulturoznawstwa ${ }^{38}$ wymieniała (czy raczej czynili to przytaczani przez nią badacze) następujące modele uprawiania tej dziedziny wiedzy: historyczny (najwyraźniejszy zdaniem autorki w ośrodku wrocławskim), filozoficzny (Poznań), antropologiczno-upraktyczniony (IKP Warszawa), artystyczny (Łódź). Może nurt społeczno-polityczny w wydaniu środkowoeuropejskim byłby na tym tle ciekawą propozycją? ${ }^{39} \mathrm{Na}$ koniec słowo na temat pewnej symetrii, jaką byłoby eksplicytne zaangażowanie badań kulturoznawczych w stabilność rejonu i relacji zamieszkujących go etnosów wobec anglosaskich cultural studies. Te ostatnie, jak wiadomo otwarcie polityczne i zaangażowane w tworzenie dyskursów emancypacyjnych (gender studies, studia nad nieheteronormatywnością, animal studies, postkolonializm i in.), stały się źródłem inspiracji dla części badaczy, solą w oku zaś dla innych, głównie za sprawą ich dość jasnego umiejscowienia na

${ }^{37} \mathrm{Nie}$ znaczy to, że problemy globalnych nierówności, katastrofy klimatycznej tudzież innych zagrożeń są nieistotne: są nadal palące, wskazujemy tu jednak na „ratowniczą" perspektywę konkretnych area studies.

${ }^{38}$ M. Wójcicka, Kulturoznawstwo czy kulturoznawstwa polskie?, w: Kulturoznawstwo polskie..., s. 232-233.

${ }^{39}$ Jestem daleki od oceniania istotności projektów akademickich za pomocą ich popytu wśród studentów, ale warto zauważyć, że istnieją w takim ujęciu punkty styczne $\mathrm{z}$ utrzymującym się nadal na wysokim poziomie zainteresowaniem kandydatów naukami o bezpieczeństwie. Nawiasem mówiąc, samo zaistnienie takich kierunków, motywacje udających się tam młodych ludzi i programy nauczania stanowią ciekawe zagadnienie dla kulturoznawstwa (i nie tylko) regionu. 
tradycyjnej osi „lewica-prawica” i zagrożenie kontaminacji badanych faktów przez „ideologię" ${ }^{\text {" }}$. Kulturoznawcy polscy nieraz podkreślają, jakoby polska modalność (czy raczej modalności) nauk o kulturze była daleka od ich anglosaskich kuzynów - i (przynajmniej częściowo) niechętnie patrzą na próby zaszczepienia anglosaskich praktyk na rodzimy grunt. Kulturoznawstwo ratownicze Europy Środkowo-Wschodniej jest więc propozycją podjęcia zaangażowania, cechującego praktyki cultural studies, ale w imię zagadnień znacznie mniej polaryzujących bada$\mathrm{czy}^{41}$.

Spróbujmy więc stworzyć definicję Kulturoznawstwo ratownicze Euopy Środkowo-Wschodniej (licząc, że czas pomoże wykształcić poręczniejszy termin) w sposób najprostszy, czyli cytując bohaterkę naszego tekstu. Jest takie podejście do pracy naukowej potrzebne, by

uczyć myślenia, a zwłaszcza myślenia krytycznego, i chronić przed dogmatyzmem; by wzmacniać podmiotowość i poczucie wpływu jednostki i grup na dokonujące się dookoła zmiany; by tworzyć i odbudowywać relacje wspólnotowe; by stale stawiać pytania o człowieka (co to znaczy być człowiekiem w wieloetnicznej, wieloreligijnej, a także wielogatunkowej zbiorowości); by rozbudzać empatię oraz impuls moralny, który powinien uruchamiać się w trudnych sytuacjach wyboru; wreszcie - by uczyć ludzi, jak się buntować. [...] Humanistyka [a więc także kulturoznawstwo przyp. autora] powinna ponadto humanizować, tj. kształtować człowieka (także jako godnego przedstawiciela swojego gatunku) ${ }^{42}$.

Zasadnicze pytanie jednak brzmi: jak w praktyce realizować takie założenia? Jak przekuć manifest w program? Jak miałyby wyglądać badania? Jakich narzędzi używać, jakie ujęcia forować? Czy konsekwencje tego projektu da się ograniczyć do pola badań naukowych? Przynajmniej na ostatnie z pytań mogę odpowiedzieć krótko: nie. Sądzę, że

${ }^{40}$ Por. P. J. Fereński, Jedenasty język. Przeszłość i przyszłość, s. 330.

${ }^{41}$ Zaznaczyć należy, że uważam, iż ww. badania, wrzucane zbiorczo do worka cultural studies, są niezwykle cenne i winny być kontynuowane. Zresztą ich popularność nie budzi też wątpliwości, że będą.

${ }^{42}$ E. Domańska, Historia ratownicza, s. 25. 
odpowiedzi należy szukać wielotorowo: w przestrzeni metodologii badań, etyki akademickiej oraz na planie moralnym jednostki, ostatecznie zaś spinając owe odpowiedzi klamrą - pozornie - trywialnej kategorii użyteczności.

Pytanie o metodologiczne konsekwencje „kulturoznawstwa ratowniczego" jest ważne zwłaszcza w świetle postulowanej przez Domańską reprofesjonalizacji badań, zwrotu ku empirii i solidnego osadzenia metodologicznego. To ostatnie jest wyzwaniem badaczy od narodzin dyscypliny i nie widzimy możliwości rozwiązania tego problemu w ramach tego tekstu ${ }^{43}$. Propozycją czyniącą zadość wcześniej wymionemu postulatowi autorki Historii ratowniczej jest częstsze sięganie po badania multidyscyplinarne i wielozespołowe - miast autorskich interdyscyplinarnych ${ }^{44}$, dominujących w pracach kulturoznawczych. Nadto wartościowe wydają się coraz popularniejsze tzw. badania w działaniu, które oprócz kumulacji wiedzy prowadzą - za sprawą aktywnego uczestnictwa z przedmiotem badania, (np. mniejszością narodową) - do realnych, nawet jeśli o ograniczonym zasięgu - przemian postaw i u badaczy, i wśród badanych ${ }^{45}$. Wydaje się zresztą, że nie o konkretne metody tu chodzi, lecz o uznanie praktyk badawczych jako „[nie]odrębnego od in-

${ }^{43}$ Uczciwość badawcza, której wymaga Domańska, każe przyznać, że nie widzę tego rozwiązania i poza granicami tego tekstu.

${ }^{44}$ Mam na myśli zastąpienie interdyscyplinarności, czyli sięgania po różne idiomy w ramach jednego wywodu, multidyscyplinarnością, czyli użyciu metod różnych dyscyplin połączonych wspólnym przedmiotem badań. Np. jedno badanie wspólnotowej dynamiki Euromajdanu w dwóch studiach: przeprowadzona przez psychologa społecznego analiza dynamiki grupy zestawiona z badaniem tekstualno-komunikacyjnego uniwersum tego samego przedmiotu badania, zwieńczone wspólną próbą syntetycznego komentarza. Taka propozycja oczywiście budzi szereg problemów, z których niemałym okazałyby się kwestie najniższe: ambicjonalne, zdolności kooperacji, kwestia dzielenia się nagrodą - to jest punktacją za publikację, i jest rzadko praktykowana w krajowej humanistyce, ale może i to jest zagadnienie warte namysłu i zmiany. Zresztą humanistyka ratownicza ma krzewić postawy wspólnotowe i uczyć współpracy.

${ }^{45}$ A. Skórzyńska, Czy możliwe jest kulturoznawstwo aktywistyczne, „Prace Kulturoznawcze" 19/2016 (Wrocław), s. 17. 
nych społecznych praktyk"46, zatem o zaniechanie dychotomii episteme/ phronesis i uznanie, że i jedna, i druga są możliwe do rozdzielenia tylko w kartezjańskich medytacjach. Na osobną wzmiankę zasługuje zajęcie pozornie trywialne: nauka języków. Trudno jednak zaprzeczyć, że konsekwencją przyjęcia perspektywy ratowniczej winno być stawianie w procesie edukacji na pierwszym planie tych kompetencji, które ułatwiają nawiązywanie relacji. Język i fizyczna bliskość zaś są w tej materii nie do zastąpienia.

Kolejne z pól, na których można by szukać sposobów na realizację postulatów „humanistyki ratowniczej”, to etyka akademicka oraz plan moralny jednostki. Trudno wypowiedzieć się w tym temacie, nie wpadając $\mathrm{w}$ defetyzm robiący użytek ze zgranego schematu degeneracji, a w efekcie sprowadzający się do narzekań, że ,akademicy nie są takimi samymi ludźmi, jakimi onegdaj byli”. Prawdą jest natomiast, że zastąpienie uniwersytetu jako miejsca transferu wartości (różnorodnych, dodajmy) - uniwersytetem-instytucją zajmującą się transferem wiedzy ważonej użytecznością ${ }^{47}$, jest transformacją oddalającą od postulatów Domańskiej. Nie ma jednak z tej sytuacji wyjścia innego niż odwołanie się do indywidualnej moralności każdego badacza i nawoływanie do „robienia” nauki (zarówno badań, jak i dydaktyki) samodzielnie w taki sposób, który nigdy nie traci z pola widzenia odpowiedzialności za innych - tak słuchaczy, badanych, jak i tych, którzy dopiero nadejdą i kto wie - będą mieli i możliwość, i chęć nas czytać48.

\footnotetext{
${ }^{46}$ Tamże, s. 32.

${ }^{47}$ Specyficznym rodzajem użyteczności, warto dodać, której pole znaczeniowe definiuje kapitalistyczny rynek pracy.

${ }^{48} \mathrm{~W}$ tym miejscu odsyłam do bardzo poruszającej, przytaczanej przez Marię Janion anegdoty o włoskim badaczu, Ernesto De Martino. Ten wybitny naukowiec, już po zakończeniu badań terenowych nad jedną z ostatnich tarantystek („ludzi ukąszonych najczęściej przez tarantulę i leczonych przez miejscową ludność muzyką, tańcem i barwami”, jak thumaczy Janion), i powrocie do Rzymu otrzymali telegram o nawrocie objawów u badanej dziewczyny. „Przypominał on [telegram] w sposób nieco drastyczny, że tarantyści nie byli tylko dokumentem z innej epoki, lecz przede wszystkim żywymi ludźmi, wobec których mieliśmy aktualne zobowiązania. W telegramie
} 
Powyższe, niewątpliwie wzniosłe czy wręcz ryzykujące patos, rozważania jak klamra zamyka kategoria zupełnie innej wagi: użyteczność. Bo temu służy - jeśli go dobrze rozumiem - projekt Domańskiej. Jest przede wszystkim wezwaniem do prowadzenia działalności naukowej, tak by dzięki niej nie przestała istnieć przestrzeń (zniszczona katastrofą klimatyczną czy jakże typową dla naszego regionu świata wojną), w której dalej można oddawać się temu zajęciu, które Wittgenstein nazwał próbowaniem zrozumienia tego, co mamy wprost przed oczami ${ }^{49}$.

\section{Bibliografia}

Domańska Ewa, Historia egzystencjalna. Krytyczne studium narratywizmu i humanistyki zaangażowanej, WN PWN, Warszawa 2012.

Domańska Ewa, Historie niekonwencjonalne, Wydawnictwo Poznańskie, Poznań 2006.

Domańska Ewa, Luka paradygmatyczna we wspótczesnej humanistyce w: Mody. Teorie i praktyki, red. E. Winniecka, Wydawnictwo Poznańskiego Towarzystwa Przyjaciół Nauk, Poznań 2018.

Domańska Ewa, Posthumanism, audycja w cyklu rozmów z prof. Robertem Harrisonem Entitled opinions (about Life and Literature), 6 czerwca 2012, https:// podcasts.apple.com/p1/podcast/entitled-opinions-about-life-and-literature/ id81415836 [dostęp 29.10.2019].

Domańska Ewa, Sprawiedliwość epistemiczna w humanistyce zaangażowanej, „Teksty Drugie” 1/2017.

Fereński Piotr Jakub, Jedenasty język. Przeszłość i przyszłość, w: Kulturoznawstwo polskie. Przeszłość, przestrzeń, perspektywy, red. P. J. Fereński, A. Gomóła, M. Wójcicka, M. Zdrodowska, Wydawnictwo Naukowe Katedra, Gdańsk 2018.

Graczyk Piotr, Nick Land i hiperprawica deleuzjańska, „Kronos” 3/2015.

Janion Maria, Humanistyka: poznanie i terapia, PIW, Warszawa 1974.

Konecki Krzysztof Tomasz, Studia z metodologii badań jakościowych: teoria ugruntowana, WN PWN, Warszawa 2012.

pisano: Carmela tańczy. Przyjedźcie”, za: M. Janion, Humanistyka: poznanie i terapia, PIW, Warszawa, 1974, s. 232.

${ }^{49}$ L. Wittgenstein, Dociekania filozoficzne, przeł. B. Wolniewicz, WN PWN, Warszawa 2007, s. 65. 
Kuziak Michał, Czy polska humanistyka jest polityczna? Rekonesans, w: Nowa humanistyka. Zajmowanie pozycji, negocjowanie autonomii, Wydawnictwo IBL PAN, Warszawa 2017.

Marzec Andrzej, „Jesteśmy połaczonym z soba światem” - Timothy Morton $i$ widmo innej wspólnoty, ,,Teksty Drugie” 2/2018.

Skórzyńska Agata, Czy możliwe jest kulturoznawstwo aktywistyczne, „Prace kulturoznawcze" 19/2016 (Wrocław).

Sloterdijk Peter, Musisz życie swe odmienić, przeł. J. Janiszewski, WN PWN, Warszawa 2014.

Walczak Monika, Między dyscyplina a badaniami interdyscyplinarnymi: uwagi o metodologicznym statusie kulturoznawstwa, „Roczniki Kulturoznawcze” $1 / 2010$.

Wittgenstein Ludwig, Dociekania filozoficzne, przeł. B. Wolniewicz, WN PWN, Warszawa 2007.

Włodarczyk Rafał, Ideologia, Teoria, Edukacja. Myśl Ericha Fromma jako inspiracja dla pedagogiki współczesnej, Impuls, Kraków 2016.

Wójcicka Marta, Kulturoznawstwo czy kulturoznawstwa polskie?, w: Kulturoznawstwo polskie. Przeszłość, przestrzeń, perspektywy, red. P. J. Fereński, A. Gomóła, M. Wójcicka, M. Zdrodowska Wydawnictwo Naukowe Katedra, Gdańsk 2018.

Domańska Ewa, Historia ratownicza, „Teksty Drugie” 5/2014.

\section{Rescue cultural studies or what could intercultural studies of Central and Eastern Europe learn from Ewa Domańska}

The article reflects on possibility that Ewa Domańska's ideas, most prominently "rescue history" and "existential history", could be of great benefit to the cultural studies of Central and Eastern Europe. Domańska's project has, at its heart, the notion of building knowledge which maximises the chance of survival in the face of an uncertain future. As such, the article argues, her ideas marry perfectly with studies of Central and Eastern Europe, area deeply troubled by international issues. A latter section of the article focuses on the practicalities of using "rescue history" ideas within the cultural studies of Eastern Europe.

Keywords: Ewa Domańska, rescue history, cultural studies, engaged humanities, New Humanities 